NOTE

\title{
Spatial patterns of diatom and dinoflagellate seasonal cycles in the NE Atlantic Ocean
}

\author{
Abigail McQuatters-Gollop ${ }^{1,2, *}$, Dionysios E. Raitsos ${ }^{1,2}$, Martin Edwards $^{2}$, \\ Martin J. Attrill ${ }^{1}$ \\ ${ }^{1}$ Marine Institute, University of Plymouth, Drake Circus, Plymouth PL4 8AA, UK \\ ${ }^{2}$ Sir Alister Hardy Foundation for Ocean Science, The Laboratory, Citadel Hill, Plymouth PL1 2PB, UK
}

\begin{abstract}
Within the phytoplankton community, diatoms and dinoflagellates have diverse roles, different spatial patterns and contrasting trophic value: diatoms are the foundation of the copepodfish food web while dinoflagellates appear less valuable. Changes in relative abundance of these two phytoplankton groups have been linked to pressures such as climate change and eutrophication. Spatially comprehensive data on the seasonal distribution of diatoms and dinoflagellates in noncoastal waters is limited; thus, information concerning their distribution in the open ocean is particularly useful. Here we present spatial and temporal patterns of diatom and dinoflagellate seasonal cycles in the coastal and open NE Atlantic Ocean based on >100 000 Continuous Plankton Recorder (CPR) samples. This analysis is presented in the form of monthly composite maps of the spatial distribution of diatoms and dinoflagellates and their relative abundances from 1958 to 2003, whose monthly time scale allows the biogeographical exploration of seasonal cycle patterns for each group. The diatom bloom peaks first during May, with a smaller peak in late summer, while dinoflagellate abundance reaches its peak in August. Spatially, the blooms of both groups begin in the North Sea and spread outward across the NE Atlantic region. Throughout the year, dinoflagellates and diatoms are generally most abundant in the central and southern North Sea, while the minimum abundances of both groups occur to the south of Iceland. These spatially detailed seasonal data are not yet available from remote sensing sources and may be used for the validation of current models and research as well as coastal and resource management.
\end{abstract}

KEY WORDS: North Atlantic phytoplankton - Seasonal cycles - Spatial patterns - Diatoms · Dinoflagellates Resale or republication not permitted without written consent of the publisher

\section{INTRODUCTION}

Variations in phytoplankton community composition impact the pelagic ecosystem through changes in trophic transfer efficiency (Nagata et al. 1996), food web structure and nutritional content provided to higher trophic levels (Pedersen et al. 1999). Diatoms and dinoflagellates play unique roles in ecosystem processes. Within the phytoplankton, diatoms form the base of the copepod-fish food web while the smaller, unpalatable, and less nutritious dinoflagellates are often considered trophic dead ends and can result in food webs culminating in non-fodder gelatinous organisms to the detriment of fish (Verity \& Smetacek 1996). Thus the spatial distributions of diatoms and dinoflagellates throughout the year may influence the seasonal distributions of higher trophic organisms. Additionally, such shifts in phytoplankton community composition have been attributed to eutrophication (Micheli 1999) and climate change (Richardson \& Schoeman 2004, Leterme et al. 2006). In order for these links to be confirmed and for these environmental changes to be assessed and monitored, some indication of 'typical' community composition throughout the 
year is first needed; however, for most of the NE Atlantic, particularly open waters, a spatially detailed description of the seasonal patterns of diatom and dinoflagellate abundances is unavailable.

Despite the significant roles of phytoplankton functional groups in the World Ocean, information about their distribution and comparative seasonal cycles in open oceanic areas is limited due to the lack of comprehensive datasets (Edwards et al. 2001). The Continuous Plankton Recorder (CPR) survey, an upper layer plankton monitoring programme, is unique in providing comprehensive data on the spatial and temporal distributions of diatoms and dinoflagellates in the NE Atlantic Ocean and North Sea. Because it is not yet possible to differentiate diatom and dinoflagellates based on current remote sensing algorithms, the CPR survey is able to provide large scale information not available through remote sensing (Sathyendranath et al. 2004).

Recently, Beaugrand (2004) published a comprehensive CPR plankton atlas detailing the abundance and presence of various phytoplankton species in the NE Atlantic. Whilst the atlas is an invaluable reference illustrating the spatial distribution of individual phytoplankton taxa, it does not explore the distribution of diatoms and dinoflagellates at the functional group scale. However, temporal variation of major phytoplankton groups across large areas of the NE Atlantic has recently been investigated (Leterme et al. 2005, 2006), but this was done on a large scale and seasonal cycles were not examined.

Here we present spatial and temporal patterns of diatom and dinoflagellate seasonal cycles in the coastal and open NE Atlantic Ocean based on $>100000$ CPR samples. This analysis is presented in the form of monthly composite maps of the spatial distribution of both major taxonomic groups from 1958 to 2003, as well as maps of their relative abundances throughout the calendar year. These are the first maps of this kind to be developed for the NE Atlantic and the monthly time scale allows the biogeographical exploration of seasonal cycle patterns for each group.

\section{MATERIALS AND METHODS}

The CPR has been operating in the NE Atlantic and North Sea since 1931 (Fig. 1 in Edwards et al. 2001) and measures the abundance of approximately 200 phytoplankton taxa (Warner \& Hays 1994). Full details of the operation of the CPR have been published extensively elsewhere (e.g. Warner \& Hays 1994, Batten et al. 2003) but are summarised here. The CPR collects samples using a high-speed plankton recorder that is towed behind 'ships of opportunity' through the surface layer of the ocean ( 10 m depth). Water passes through the recorder, and plankton are filtered by a slow moving silk layer (mesh size $270 \mu \mathrm{m}$ ). A second layer of silk covers the first and both are reeled into a tank containing $4 \%$ formaldehyde. Because phytoplankton cells are recorded as either present or absent across 20 microscopic fields spanning each section of silk, CPR phytoplankton abundance is a semiquantitative estimate (i.e. the species is recorded once per field independent of the number of cells in a field). However, the proportion of cells captured by the silk reflects the major changes in abundance, distribution, and community composition of the phytoplankton (Robinson 1970), and is consistent and comparable over time. (For more information on CPR sampling methods see Batten et al. 2003). The collection and analysis of CPR samples have been carried out using a consistent methodological approach since 1958, making the CPR survey the longest continuous dataset of its kind in the world (Edwards \& Richardson 2004).

Total diatom and dinoflagellate abundances were calculated for each CPR sample; because unarmoured dinoflagellates are often destroyed by the CPR collection process, only armoured flagellates were considered in the group's total abundance. Abundance data were $\log _{10}(x+1)$ transformed to ensure that the data approximate a normal distribution. Monthly composite maps of diatoms and dinoflagellates were produced using the kriging method of interpolation on a $1 \times 1^{\circ}$ data grid (Caruso \& Quarta 1998) thereby creating a continuous distribution of phytoplankton group abundances. Kriging, like all geostatistical methods, assumes that spatial structures are stable in time, at least for the duration of the sampling period (Simard et al. 1992). However, this cannot be assumed of CPR data due to its $45 \mathrm{yr}$ sampling period. This problem has been resolved by portioning the data into shorter temporal periods and treating each temporally partitioned dataset individually (Edwards 2000). Thus, the period of study was refined into 9 shorter time periods of generally 5 yr each (1958-1962, 1963-1967, 1968- 1972, 1973-1977, 1978-1982, 1983-1987, 1988-1992, 19931997, 1998-2003). Next, 12 monthly averaged maps were created for each of the $5 \mathrm{yr}$ intervals using the kriging method described above. For each calendar month, all 9 of the $5 \mathrm{yr}$ maps of that month were then averaged at each grid node and kriging was used to create monthly composite maps showing the mean spatial distribution for each month over the entire study period. This process was performed separately for diatoms and dinoflagellates. Each monthly composite map is made up of approximately 8000 in situ CPR samples taken between 1958 and 2003. In order to explore phytoplankton community composition, the monthly composite maps of diatoms and dinoflagel- 
a) Spatial distribution of diatoms
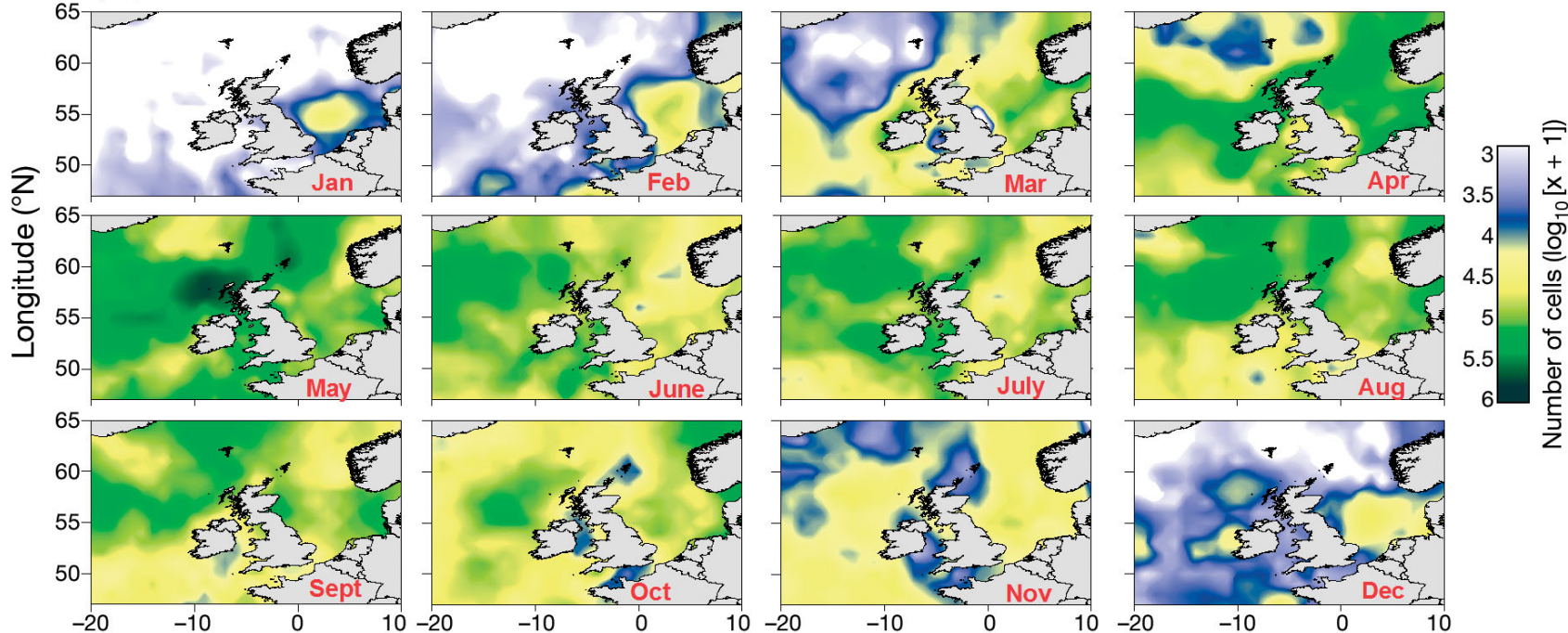

b) Spatial distribution of dinoflagellates
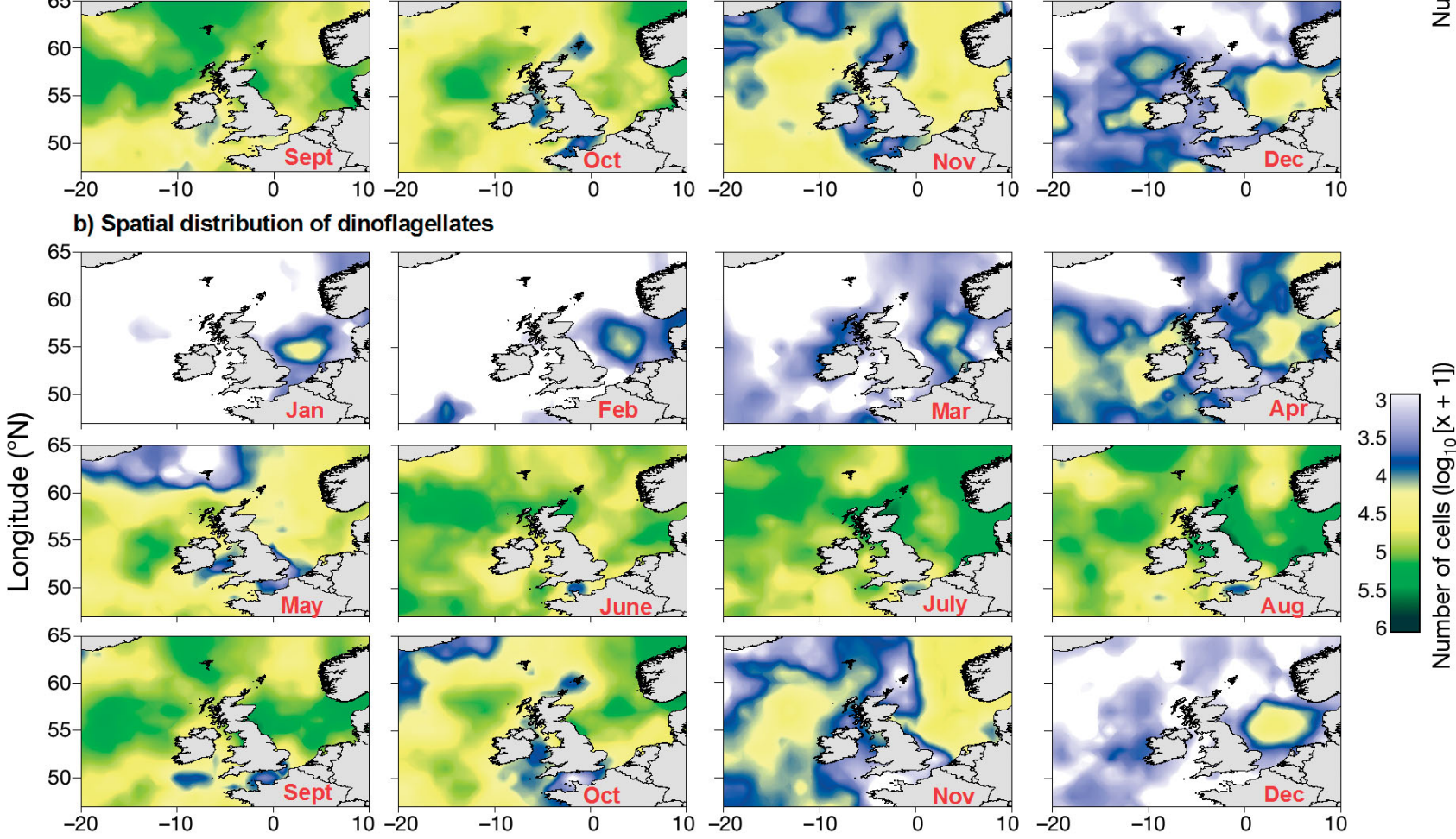

c) Relative abundance of diatoms and dinoflagellates
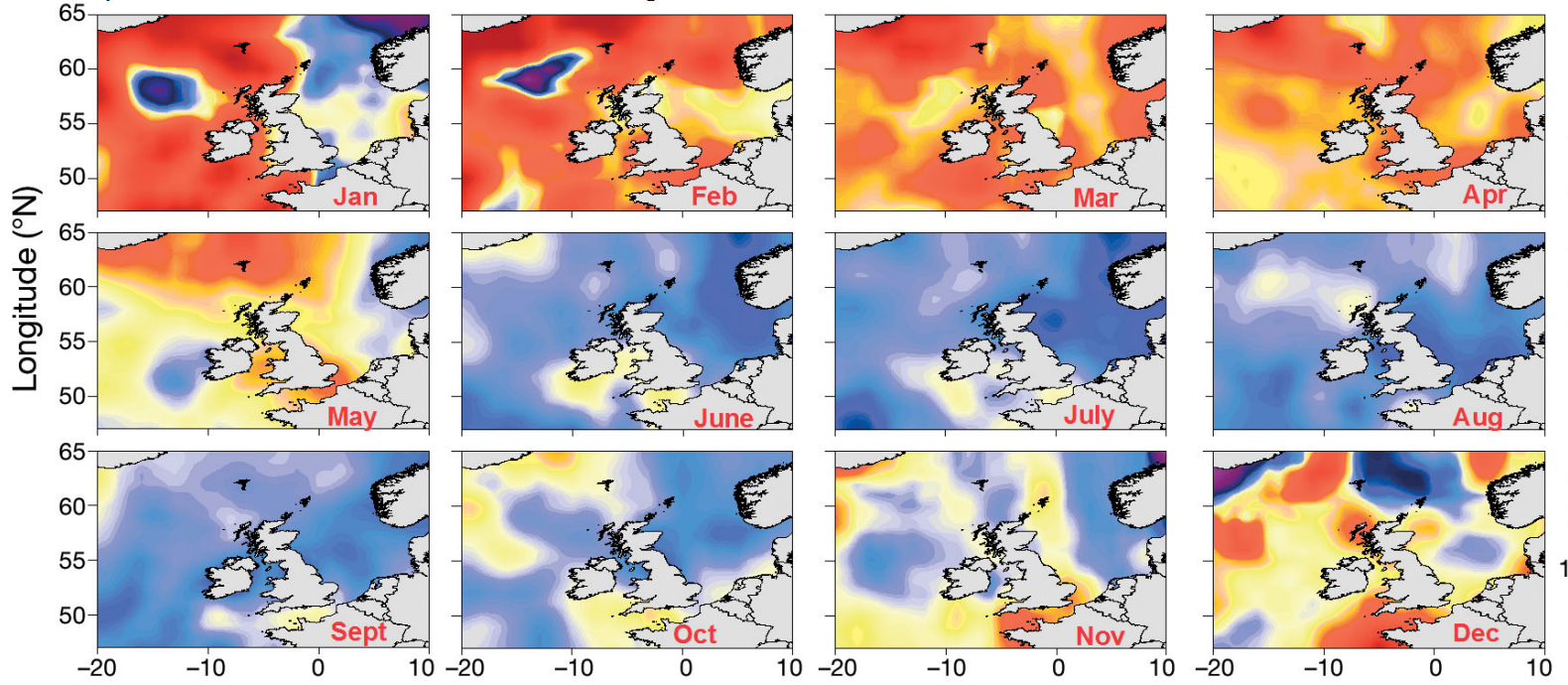

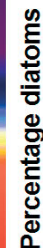

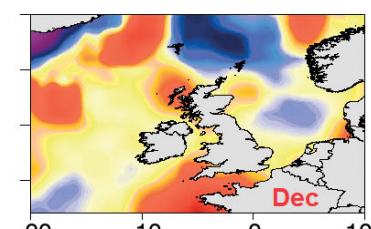

Latitude $\left({ }^{\circ} \mathrm{E}\right)$

Fig. 1. Mean monthly spatial patterns of (a) diatoms, (b) dinoflagellates, and (c) their relative community abundances (as percentage diatoms) in NE Atlantic during period 1958 to 2003 
lates were then used to calculate the relative abundance (measured as percent diatoms) for each calendar month.

\section{RESULTS}

Across the survey time period, the spring diatom bloom, defined here as the annual rapid increase in phytoplankton growth and abundance, commenced in the shallow areas of the North Sea in March (Figs. 1a \& 2). Its timing was predominantly controlled by light penetration, the amount of light available in the euphotic zone being determined by day length, strength of solar radiation, cloudiness (most notably in winter), degree of mixing and amount of suspended matter in the water column (Edwards 2000). Therefore, in March the shallow areas of the North Sea were the first to show an increase in diatom abundance as light penetration increased. The diatom bloom also began in March in the Skagerrak, but in this case as a result of haline stratification due to Baltic inflow rather than because of shallow depth and low amounts of suspended matter (Richardson \& Christoffersen 1991).

During April, diatom abundance increased outwards from shallow to deeper waters, encompassing nearly the entire main shelf area; the diatom bloom was most intense in the North Sea and the shelf area west of Scotland. At this time, diatom abundance to the south of Iceland remained somewhat lower, probably due to the colder water and deep vertical mixing in that region, which delays the onset of stratification and consequently the spring bloom at higher latitudes (Edwards 2000).

By May, the diatom bloom was at its peak, covering nearly the entire NE Atlantic, although a reduction in abundance in the Skagerrak and Norwegian Trench indicated the end of the diatom spring bloom in those areas. During May, the dinoflagellate bloom began in the Skagerrak, the Rockall Trough and the Porcupine Bank (Fig. 1b). In late spring and summer, the phytoplankton community composition across most of the NE Atlantic consisted of a greater number of dinoflagellates than diatoms (Fig. 1c). Because the water column was stratified, phytoplankton depleted upper layer nutrients, and diatoms (opportunists) gave way to flagellates (competitors) and eventually dinoflagellates (stress-tolerators), both of which are adapted to survival in low nutrient, stable waters (Margalef 1978, Holligan 1987).

During June, the spring diatom bloom gradually continued to recede across the region, while the dinoflagellate bloom spread throughout most of the NE Atlantic, except for the coastal area around the southern United Kingdom and Ireland, which remained well mixed and unstratified due to tidal turbulence (Pingree $\&$ Griffiths 1978). Diatom abundance again increased across the entire region in July, and by August was especially high in the Skagerrak, the German Bight, and the waters north of Norway as well as those to the NW of Ireland. The dinoflagellate bloom peaked during July and August, with particularly high abundances persisting in the productive areas of the Skagerrak, German Bight and the Shetland and Orkney Island areas of Scotland. After August, the blooms of both taxonomic groups began to decrease in abundance, starting in the Celtic Sea and continuing northwards throughout the autumn months.

During autumn, cooler water temperatures and increased storms caused the thermocline to start to erode, allowing the mixing of cold, nutrient rich bottom waters with warm, nutrient depleted surface waters (Holligan 1987). Thus, as stratification decreased, autumn diatom and dinoflagellate blooms occurred in parts of the North Sea, Norwegian Trench and deeper shelf waters. During September, the diatom bloom continued to gradually recede in the Celtic Sea, Irish Sea, the Norwegian Trench and south of Iceland, although it remained strongest around the Faroe Islands and Rockall Trough. The dinoflagellate bloom also still covered much of the NE Atlantic, although abundance continued to decline compared to previous months, especially around the British Isles and to the south of Iceland.

By October, diatom and dinoflagellates only remained abundant in the Rockall Trough, shallow areas of the North Sea, the Porcupine Bank and north of Norway. Strengthening wind and wave action resulted in increased turbidity, which along with decreasing solar radiation caused the abundance of both phytoplankton groups to decline during November. Because NE Atlantic waters were light limited in winter, and remained cool, turbulent, and well-mixed throughout the winter months (OSPAR Commission 2000), the abundance of both phytoplankton groups decreased throughout winter, with diatoms reaching a minimum in January and dinoflagellates reaching a minimum in February. However, even during the winter, the abundance of both groups was highest in the shallow areas of the Dogger Bank and southern areas of the North Sea. These areas were the first to bloom in March when the seasonal cycle began again.

Like the monthly abundances of diatoms and dinoflagellates, the relative community composition of each functional group (measured as percent diatoms) was patchy across both space and time (Fig. 1c). However, some definite seasonal patterns can be observed. During winter and spring diatoms were generally more abundant than dinoflagellates across the NE Atlantic region, while the phytoplankton community was richer in dinoflagellates than diatoms in summer and 


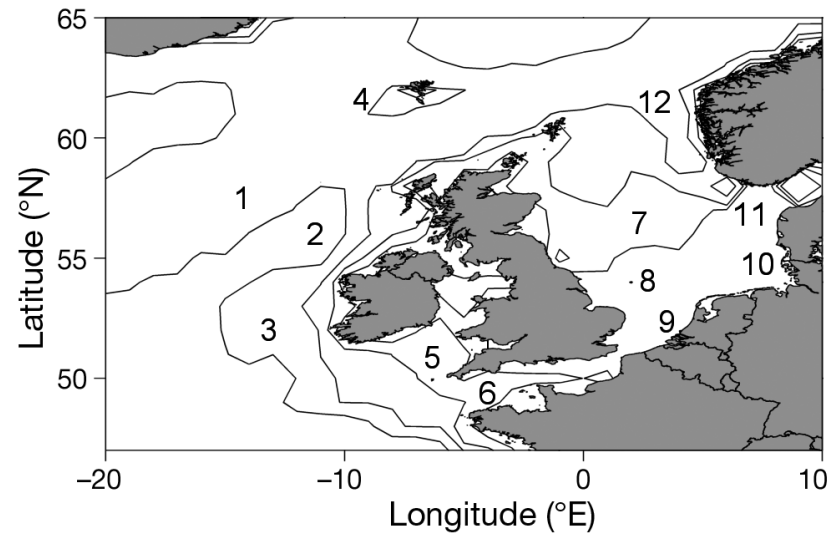

Fig. 2. Bathymetric map with detailed location names of NE Atlantic and North Sea regions - 1: Rockall Plateau; 2: Rockall Trough; 3: Porcupine Bank; 4: Faroe Islands; 5: Irish Sea; 6: English Channel; 7: North Sea; 8: Dogger Bank; 9: Southern Bight; 10: German Bight; 11: Skagerrak; 12: Norwegian Trench. 50, 100, 200, and $2000 \mathrm{~m}$ contour lines are shown

autumn. The North Sea, Norwegian Trench, Skagerrak and Rockall regions showed the lowest percentage of diatoms during summer months $(<45 \%)$, while relative diatom abundance remained higher ( 55\%) throughout the summer in the English Channel, the Celtic Sea and to the south and east of Iceland. During winter months, the phytoplankton in most of the NE Atlantic may consist of up to $90 \%$ diatoms; however, this was not the case for the North Sea, where phytoplankton was rarely composed of more than $70 \%$ diatoms. Hydrographic explanations for the variations in diatom and dinoflagellate abundance have been provided above, but additional research is required to rule out influence by anthropogenic factors, particularly in coastal areas.

\section{DISCUSSION}

The analysis presented here provides a description of phytoplankton seasonal cycles across the NE Atlantic and North Sea and their relationships to the hydrographical characteristics of the region based on $>50 \mathrm{yr}$ of data. These maps contribute information intended to help us better understand how the spatial distribution of phytoplankton groups can influence ecosystem structure and functioning as well as to illustrate the patchy nature of phytoplankton distribution in the NE Atlantic.

In summary, the two phytoplankton groups display dissimilar bloom patterns, with the diatom spring bloom peaking during May before gradually declining through mid-summer and then weakly peaking again in late summer. Dinoflagellates bloom most intensely during late summer, peaking in August, before progressively declining throughout autumn. Both groups maintain only a minimum abundance during winter months. Spatially, dinoflagellates and diatoms both exhibit highest abundances in the central and southern North Sea, while dinoflagellates also display particularly high abundance in the Skagerrak and diatoms are highly abundant in waters to the west of Scotland. The minimum abundances of both groups occur to the south of Iceland. These general patterns provide the framework for more detailed exploration of spatial and temporal trends in smaller geographic areas and across more refined time periods in order to explore finer scale changes. We believe that additional knowledge regarding trends in long-term spatial and temporal variation in phytoplankton functional group distribution can provide insights into the effects of climate change and anthropogenic pressures on primary productivity in the NE Atlantic.

\section{LITERATURE CITED}

Batten SD, Clark R, Flinkman J, Hays G and 6 others (2003) CPR sampling: the technical background, materials and methods, consistency and comparability. Prog Oceanogr 57:193-215

Beaugrand G (2004) Continuous plankton records: plankton atlas of the North Atlantic Ocean (1958-1999). I. Introduction and methodology. Mar Ecol Prog Ser CPR(Suppl): $3-10$

Caruso C, Quarta F (1998) Interpolation methods comparison. Comput Math Appl 35:109-126

Edwards M (2000) Large-scale temporal and spatial patterns of marine phytoplankton and climate variability in the North Atlantic. PhD dissertation, University of Plymouth

Edwards M, Richardson AJ (2004) Impact of climate change on marine pelagic phenology and trophic mismatch. Nature 430:881-884

Edwards M, Reid P, Planque B (2001) Long-term and regional variability of phytoplankton biomass in the NE Atlantic (1960-1995). ICES J Mar Sci 58:39-49

Holligan PM (1987) The physical environment of exceptional phytoplankton blooms in the NE Atlantic. Rapp P-V Réun Cons Int Explor Mer 187:9-18

Leterme SC, Edwards M, Reid PC, John AWG, Attrill MJ, Seuront L (2005) Decadal basin-scale changes in diatoms, dinoflagellates, and phytoplankton color across the North Atlantic. Limnol Oceanogr 50:1244-1253

Leterme SC, Seuront L, Edwards M (2006) Differential contribution of diatoms and dinoflagellates to phytoplankton biomass in the NE Atlantic Ocean and the North Sea. Mar Ecol Prog Ser 312:57-65

Margalef R (1978) Life forms of phytoplankton as survival alternatives in an unstable environment. Oceanol Acta 1: 493-509

Micheli F (1999) Eutrophication, fisheries, and consumer-resource dynamics in marine pelagic ecosystems. Science 285

Nagata T, Takai K, Kawabata KI, Nakanishi M, Urabe J (1996) The trophic transfer via a picoplankton-flagellatecopepod food chain during a picocyanobacterial bloom in Lake Biwa. Arch Hydrobiol 137:145-160 
OSPAR Com (Oslo-Paris Commission) for the Protection of the Marine Environment of the North-East Atlantic (2000) Quality status report 2000. OSPAR Commission, London

Pedersen L, Jensen HM, Burmeister A, Hansen BW (1999) The significance of food web structure for the condition and tracer lipid content of juvenile snail fish (Pisces: Liparis spp.) along $65-72^{\circ} \mathrm{N}$ off West Greenland. J Plankton Res 21:1593-1611

Pingree RD, Griffiths DK (1978) Tidal fronts on the shelf seas around the British Isles. J Geophys Res 83:4615-4622

Richardson A, Schoeman DS (2004) Climate impact on planktonic ecosystems in the Northeast Atlantic. Science 305: 1609-1612

Richardson K, Christoffersen A (1991) Seasonal distribution and production of phytoplankton in the southern Kattegat. Mar Ecol Prog Ser 78:217-227

Editorial responsibility: Howard Browman (Associate Editorin-Chief), Storebø, Norway
Robinson GA (1970) Continuous plankton records: variation in the seasonal cycle of phytoplankton in the North Atlantic. Bull Mar Ecol 6:333-345

Sathyendranath S, Watts L, Devred E, Platt T, Caverhill C, Maass H (2004) Discrimination of diatoms from other phytoplankton using ocean-colour data. Mar Ecol Prog Ser 272:59-68

Simard Y, Legendre P, Lavoie G, Marcotte D (1992) Mapping, estimating biomass, and optimizing sampling programs for spatially autocorrelated data: case study of the northern shrimp. Can J Fish Aquat Sci 49:32-45

Verity PG, Smetacek V (1996) Organism life cycles, predation, and the structure of marine pelagic systems. Mar Ecol Prog Ser 130:277-293

Warner AJ, Hays GC (1994) Sampling by the Continuous Plankton Recorder survey. Prog Oceanogr 34:237-256

Submitted: August 11, 2006; Accepted: November 19, 2006 Proofs received from author(s): May 18, 2007 